\title{
Physical Modeling of Power Unit in Power Plant with Auxiliary Transformer
}

\author{
Heorhiy Lysiak, Olena Pastukh ${ }^{*}$, Bohdan Kharchyshyn \\ Lviv Polytechnic National University, S. Bandera St. 12, Lviv, 79013, Ukraine
}

Received: March 22, 2019. Revised: April 03, 2019. Accepted: May 23, 2019.

(C) 2019 The Authors. Published by Lviv Polytechnic National University.

\begin{abstract}
The article shows the option of the first degree transformation scheme in auxiliary power supply systems of the power unit (PU). The power supply to the auxiliary receivers is carried out from the generator through the working and additional working auxiliary transformers (AAT). The method of switching on the latter one provides its operation in the source mode set by the PU current load. Experiments were carried out on a static physical model of the scheme fragment of the auxiliary power supply system with an AAT. It is confirmed that its natural properties, in contrast to the traditional schemes, provide during the normal modes, modes of external short circuits the level of voltage on the busbars, sufficient for the reliable operation of their electrical receivers. The possibility of effective research with the use of appropriate mathematical and digital models has been proved. The high adequacy of the results has been confirmed.
\end{abstract}

Keywords: power plant; auxiliary transformer; power unit; diagram.

\section{The problem in question}

One of the important tasks to be solved during the development of new circuit technical solutions of the electrical part of power units is to ensure the necessary adequacy of the comprehensive studies results of their natural properties. Conducting such studies through field experiments on existing objects is possible with a certain reconstruction, assembling special stands and requires significant costs. At the same time, the decision on the feasibility and necessity of conducting such experiments can be made if the results of previous studies using mathematical modeling and computer simulation cause certain reservations regarding their adequacy. That is why, to confirm the reliability of the results, the research is carried out using various software systems and, when possible, doing experiments on physical models.

\section{The analysis of the recent research}

In addition to the new scheme, technical decisions for the electrical part of power stations units (PU), in particular, the proposed in [1] options of the power supply systems implementation for the auxiliaries (Aux). The fundamental difference between such systems and the traditional ones is the application and circuitry of the inclusion of an additional auxiliary transformer (AAT), which works simultaneously with a working auxiliary transformer (WAT) on the busbar of the first transformation stage of the Aux power supply system. At the same time, in accordance with the chosen values of the parameters of the system elements [2], the mode of operation of the AAT will be close to the current source mode, the value of which will be determined by the current load of the PU, both in the stable operating modes and during external short circuits (s. c.). This is the AAT mode that provides the voltage level on the Aux busbars, sufficient for their electrical power [3-7]. Computer simulation allowed revealing peculiarities of the mathematical and digital models of AAT and recommendations for their implementation [8-10]. However, the physical simulation of such objects was not carried out.

\footnotetext{
* Corresponding author. Email address: olena.r.pastukh@1pnu.ua
}

This paper should be cited as: H. Lysiak, O. Pastukh, B. Kharchyshyn. Physical modeling of power unit in power plant with an auxiliary transformer. Energy Engineering and Control Systems, 2019, Vol. 5, No. 1, pp. 15 - 22. https://doi.org/10.23939/jeecs2019.01.015 


\section{The task of research}

To confirm with the experiments on the static physical model the natural properties of the electrical part of the PU with an AAT power plant in order to maintain the desired voltage level on the Aux busbar both during regular modes and during the normal modes of external three-phase short circuits, as well as the possibility of effective research with the use of appropriate mathematical and digital models and the high adequacy of the results.

\section{Presentation of the main material}

Fig. 1 depicts a schematic diagram of one of the investigated fragments of auxiliary power supply system executions for a power unit with an AAT [1]. Here the generator G through the block transformer T1 (BT) produces power to the electrical power system S. A power supply to the auxiliary power units is carried out from the generator through a working auxiliary transformer T2 and the additional operating auxiliary transformer T3. The method of switching on the latter ensures its operation in the source mode set by the PU current load. The studies, the results of which are exemplified by the unit with a capacity of $200 \mathrm{Mw}$ in [2-7], have shown that, provided certain technical characteristics of the electrical equipment are met, the voltage level at Aux busbars will remain in tolerable measures in well-established operational modes, and during external short-circuits, as demonstrated in Fig. 1, and the main formula of schemes and the same winding groups of T2 and T3 transformers can be written as follows [2]:

$$
\underline{Z}_{\mathrm{T} 2(\mathrm{~L})} / \underline{Z}_{G}=K_{\mathrm{T} 3} / K_{\mathrm{T} 2},
$$

where $\underline{Z}_{\mathrm{T} 2(\mathrm{~L})}, \underline{Z}_{\mathrm{G}}$ are complete (integrated) WAT and generator supports in the actual named units for nominal voltage of the lower voltage winding $\mathrm{L}$ of transformer $\mathrm{T} 2$ and generator stator respectively; $K_{\mathrm{T} 2}, K_{\mathrm{T} 3}$ are transformation coefficients of T2 and T3 transformers, as the ratio of higher nominal winding voltages $\mathrm{H}$ to lower ones L.

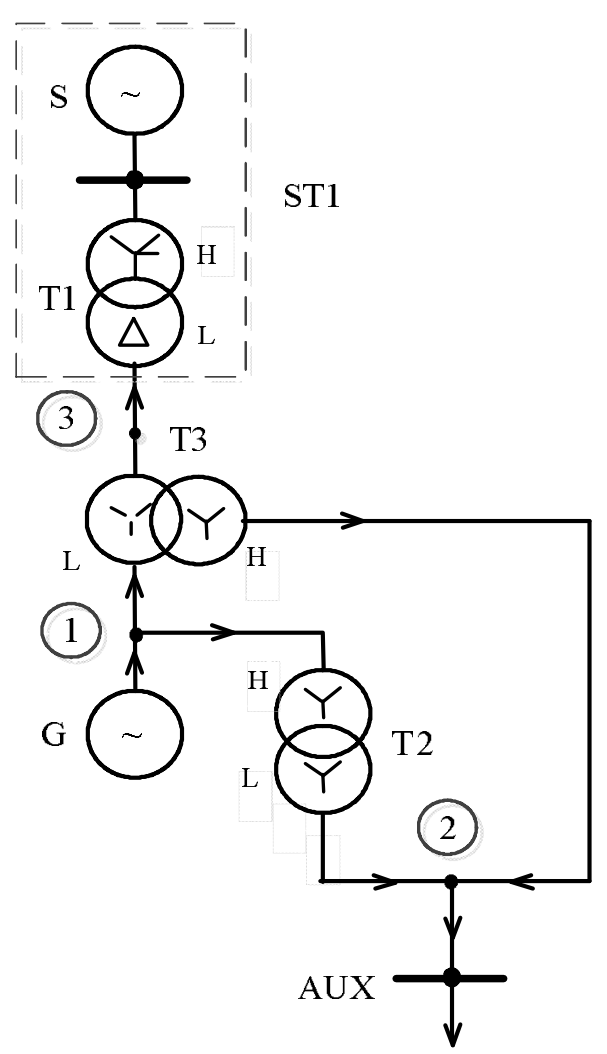

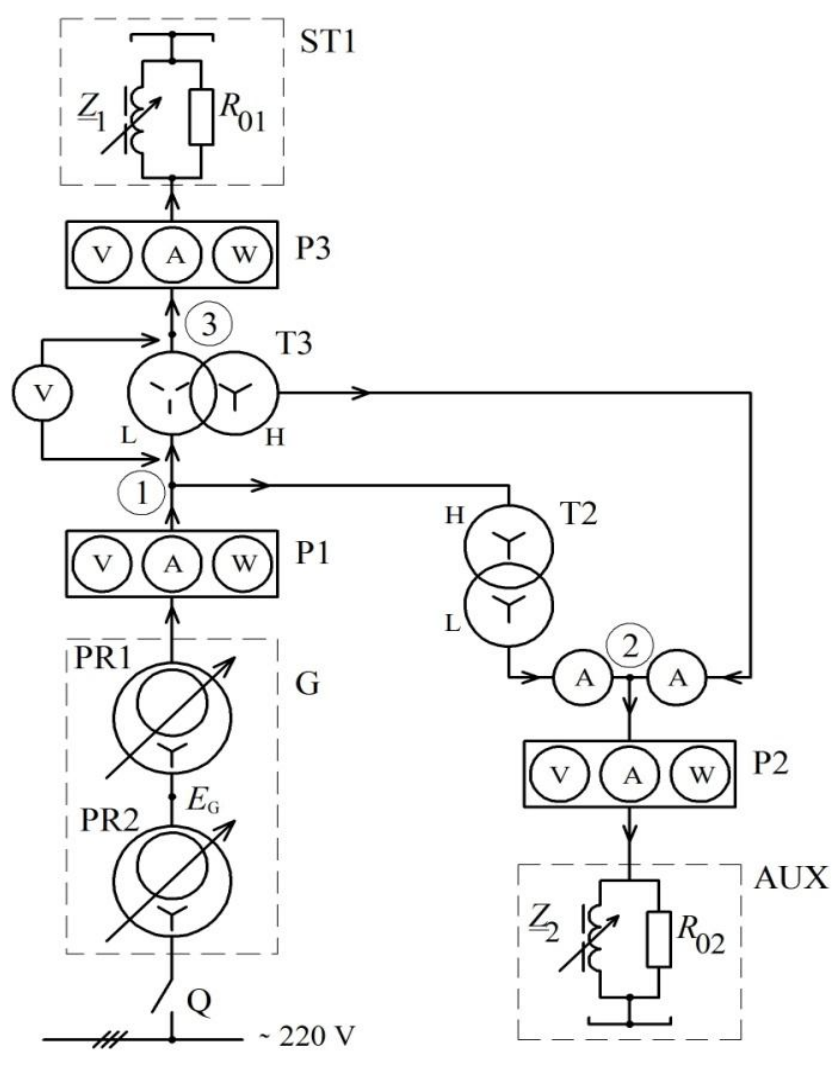

$b$

Fig.1. Circuits of the electric part of the power plant unit with the AAT: $a$ - principal model; $b$ - physical model. 
Generators and transformers of powerful units are characterized by high Q-factor, i.e. $X_{\mathrm{G}}>>R_{\mathrm{G}}$ and $X_{\mathrm{T} 2(\mathrm{~L})}>>R_{\mathrm{T} 2(\mathrm{~L})}$. Then the formula (1) is reduced to a simple relation:

$$
X_{\mathrm{T} 2(\mathrm{~L})} / X_{\mathrm{G}}=K_{\mathrm{T} 3} / K_{\mathrm{T} 2},
$$

The practice of physical modeling shows that it is usually impossible to maintain a Q-factor of physical models items, which are powered from mains $220 \mathrm{~V}$, at the level of the real high-voltage powerful electrical PU, because it requires a special performance of such elements. The task of our research did not require the exact consideration of similarity criteria for a particular real PU. Therefore, the physical model was created on the basis of available and affordable electrical equipment. Thus, for the simulation of the working and additional working Aux transformers, in particular, two identical transformers with the same parameters and transformation coefficients $\left(K_{\mathrm{T} 3}=K_{\mathrm{T} 2}\right)$ had to be used as well as two potential regulators for generator modeling. The Q-factor of transformers is an order of magnitude less than the quality of the latter. Therefore, we can only speak of a very proximate implementation of the formula (1), and only concerning modules $Z_{\mathrm{T} 2}$ and $Z_{\mathrm{G}}$ of appropriate resistance, namely:

$$
Z_{\mathrm{T} 2(\mathrm{~L})} / Z_{\mathrm{G}} \approx K_{\mathrm{T} 3} / K_{\mathrm{T} 2}=1
$$

Fig. $1 b$ demonstrates a diagram of the static physical model (PM), which was used to investigate natural properties of circuit-technical solution in Fig. 1, a. As can be seen from Fig. 1, the generator is modeled by two threephase potential regulators: PR1, the resistance of which reflects the resistance of the generator model $\underline{Z}_{\mathrm{G}}$, and which, for the normal mode of loading, generates voltage at the output of the generator model with a value close to the nominal; PR2, which is powered by a switch Q from the $220 \mathrm{~V}$ electric grid and forms the desired voltage value at the output, which is applied to the input of the PR1 and displays the generator's e.m.f. $E_{\mathrm{G}}=$ const. An auxiliary load with resistance $\underline{Z}_{\text {Aux }}$ is modeled by an Aux element consisting of three-phase active resistance batteries $R_{02}$ and an inductance coil with unbound magnetic conductors $\underline{Z}_{2}$ connected in parallel. Equivalent resistance $\underline{Z}_{\text {Aux }}$ of this element corresponds to a mode close to the nominal Aux load $\underline{S}_{\text {Aux }} \approx \underline{S}_{\text {Aux nom }}$ :

$$
\underline{Z}_{\text {Aux }}=\frac{R_{02} \cdot \underline{Z}_{2}}{R_{02}+\underline{Z}_{2}} \approx \underline{Z}_{\text {Aux nom }}=\text { const },
$$

Block transformer T1 with resistance $\underline{Z}_{\mathrm{T} 1(\mathrm{~L})}$ and system S with resistance $\underline{Z}_{\mathrm{S}(\mathrm{L})}$ are simulated by an element of ST1 from connected in parallel three-phase active resistance batteries $R_{01}$ and a coil of inductance $\underline{Z}_{1}$ with unbound magnet conductors. Equivalent resistance $\underline{Z}_{\mathrm{ST} 1}$ is determined by the formula

$$
\underline{Z}_{\mathrm{ST} 1}=\frac{R_{01} \cdot \underline{Z}_{1}}{R_{01}+\underline{Z}_{1}} \approx \underline{Z}_{\mathrm{T} 1(\mathrm{~L})}+\underline{Z}_{\mathrm{S}(\mathrm{L})}=v a r
$$

depending on the characteristic mode under study, namely:

1) $\underline{Z}_{\mathrm{ST1}(1)}=\underline{Z}_{\mathrm{T} 1(\mathrm{~L})}+\underline{Z}_{\mathrm{Snorm}(\mathrm{L})}$ the normal mode of power delivery to the system taking into account power losses in $\mathrm{T} 1 \mathrm{BT}$ and in the electric network of the system.

2) $Z_{\mathrm{T} 1(\mathrm{~L})}<Z_{\mathrm{ST} 1(2)}<Z_{\mathrm{ST} 1(1)}$ the modes of non-remote and remote from the PU three-phase short circuit in the electrical network of the system.

3) $\underline{Z}_{\mathrm{ST} 1(3)}=\underline{Z}_{\mathrm{T} 1(\mathrm{~L})}$ the mode of three-phase short circuit on the winding leads in $\mathrm{T} 1$.

4) $\underline{Z}_{\mathrm{ST1}(4)}=0$ the mode of a three-phase short circuit on the winding leads of the low voltage T1.

The coordinates of the modes were measured by sets P1, P2, P3 and the corresponding devices according to Fig. $1 b$, and the general form of the physical model is shown in Fig.2.

The mathematical model for the analysis of the established normal and emergency modes was formed in real coordinates according to the PU scheme in Fig. $1 a$, that is, taking into account the transformer T1, but without taking into consideration the transverse elements of the transformers replacement schemes. In this case, the method of 
cycling currents was used, followed by a precise analytical solution of the system of linear finite equations. Computer simulation was conducted in the Mathcad software for the purpose of:

a) before physical modelling to determine the range of values of the parameters and nominal coordinates modes of PM elements to prevent their current overloading during the established modes of three-phase short circuit;

b) after experiments on the PM with the actual values of the parameters of its elements adopted in the DM for evaluation of the research task.

It should be noted that similar studies on the described physical and digital models were also conducted for the traditional circuit of the electrical part of the PU, that is, without an additional working auxiliary transformer, for the purpose of comparative analysis of their natural properties.

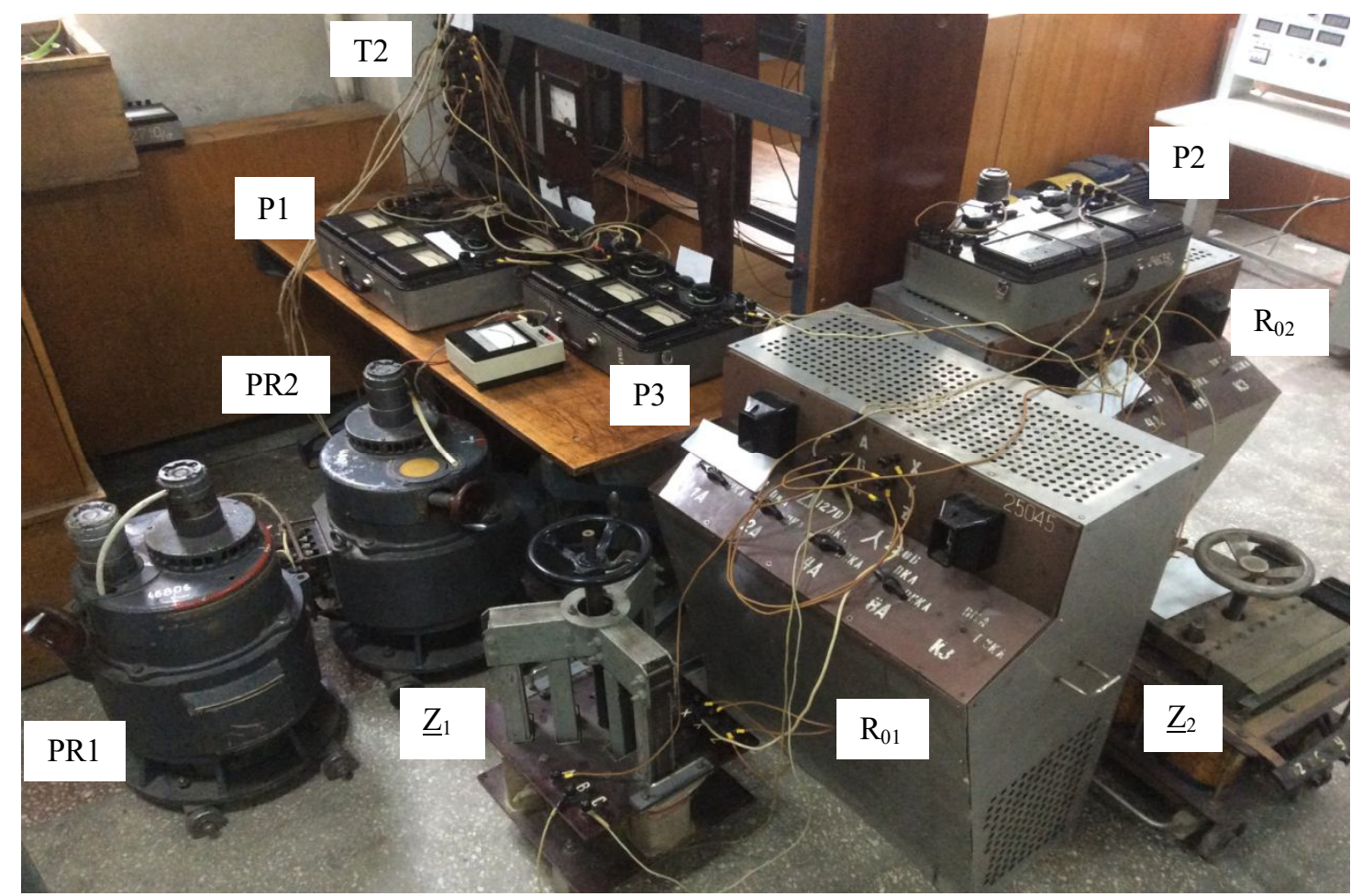

Fig 2. Physical model of the electric part fragment of the power unit in the power station with an AAT.

The following electrical equipment was involved in the physical model.

Potential regulators PR1, PR2 (induction voltage regulators VR), made as autotransformers based on the phase regulators PhR-62 with a rotating rotor.

Auxiliary elements and ST1 (each separately) the three-phase active resistance batteries with a range of possible values are connected in parallel $R_{0}=(9.8 \div 104) \Omega$ and induction coil with unbound magnetic phase conductors and a range of possible values of full resistance $\underline{Z}=[(0.363 \div 0.58)+\mathrm{j}(1.76 \div 53.47)] \Omega$.

Working and additional auxiliary working transformers are identical transformers of CES type 2.5/0,5 Y/Y-12: $S_{\text {nom }}=2.5 \mathrm{kV} \cdot \mathrm{A} ; U_{\mathrm{Hnom}}=380 \mathrm{~V} ; U_{\mathrm{Lnom}}=230 \mathrm{~V} ; K_{\mathrm{H}-\mathrm{L} \text { nom }} \approx 1.67 ; U_{\mathrm{sc} \mathrm{H}-\mathrm{L}}=15.12 \mathrm{~V} ; I_{\mathrm{sc} \mathrm{H}}=I_{\mathrm{H} \mathrm{nom}}=3.8 \mathrm{~A} ; R_{\mathrm{H}}=0.774 \Omega ;$ $R_{\mathrm{L}}=0.179 \Omega$.

Taking into account the above and based on the data analysis for the physical model, the following desirable nominal values of the mode coordinates and those close to the nominal actual values parameters of its elements parameters are adopted, the designations of which correspond to both generally accepted [11] and the designation in Fig.1.

$$
\begin{aligned}
& \text { Auxiliaries Aux: } U_{\text {Aux nom }}=30 \mathrm{~V} ; I_{\text {Aux nom }}=2 \mathrm{~A} ; \cos \varphi_{\text {Aux nom }}=0.7 ; S_{\text {Aux nom }}=104 \mathrm{~V} \cdot \mathrm{A} ; \\
& P_{\text {Aux nom }}=73 \mathrm{~W} ; Q_{\text {Aux nom }}=74 \mathrm{var} ; Z_{\text {Aux }}=8.26 \Omega ; R_{\text {Aux }}=5.92 \Omega ; X_{\text {Aux }}=5.76 \Omega . \\
& \text { TransformerT2: } K_{\mathrm{T} 2 \text { nom }} \approx 1.67 ; U_{\mathrm{T} 2 \mathrm{~L} \mathrm{nom}}=U_{\text {Aux nom }}=30 \mathrm{~V} ;
\end{aligned}
$$


$U_{\mathrm{T} 2 \mathrm{H} \mathrm{nom}}=K_{\mathrm{T} 2 \mathrm{nom}} \cdot U_{\mathrm{T} 2 \mathrm{~L} \mathrm{nom}}=50 \mathrm{~V} ; Z_{\mathrm{T} 2(\mathrm{~L})}=0.83 \Omega ; R_{\mathrm{T} 2(\mathrm{~L})}=0.48 \Omega ; X_{\mathrm{T} 2(\mathrm{~L})}=0.68 \Omega$

Transformer $\mathrm{T} 3: K_{\mathrm{T} 3 \mathrm{nom}} \approx 1.67 ; U_{\mathrm{T} 3 \mathrm{H} \mathrm{nom}}=U_{\mathrm{Aux} \mathrm{nom}}=30 \mathrm{~V}$;

$U_{\mathrm{T} 3 \mathrm{Lnom}}=\mathrm{U}_{\mathrm{T} 3 \mathrm{H} \mathrm{nom}} / K_{\mathrm{T} 2 \text { nom }}=18 \mathrm{~V} ; Z_{\mathrm{T} 3(\mathrm{H})}=2.31 \Omega ; R_{\mathrm{T} 3(\mathrm{H})}=1.33 \Omega ; X_{\mathrm{T} 3(\mathrm{H})}=1.89 \Omega$.

Generator $\mathrm{G}: U_{\mathrm{G} \text { nom }}=50 \mathrm{~V} ; E_{\mathrm{G} \text { nom }}=1.34 \cdot U_{\mathrm{G} \mathrm{nom}}=67 \mathrm{~V} ; Z_{\mathrm{G}}=4.68 \Omega ; R_{\mathrm{G}}=0.28 \Omega ; X_{\mathrm{G}}=4.67 \Omega$.

Transformer $\mathrm{T} 1: Z_{\mathrm{T} 1(\mathrm{~L})}=2.05 \Omega ; R_{\mathrm{T} 1(\mathrm{~L})}=0.6 \Omega ; X_{\mathrm{T} 1(\mathrm{~L})}=1.96 \Omega$.

System $\mathrm{S}: Z_{\mathrm{S} \text { norm }(\mathrm{L})}=10.32 \Omega ; R_{\mathrm{S} \text { norm }(\mathrm{L})}=9.87 \Omega ; X_{\mathrm{S} \text { norm }(\mathrm{L})}=3.01 \Omega$

Element ST1 for the study of the accepted characteristic modes (5):

1) $Z_{\mathrm{ST} 1(1)}=11.59 \Omega ; R_{\mathrm{ST} 1(1)}=10.47 \Omega ; X_{\mathrm{ST} 1(1)}=4.97 \Omega$.

2) $Z_{\mathrm{ST} 1(2)}=5.62 \Omega ; R_{\mathrm{ST} 1(2)}=1.04 \Omega ; X_{\mathrm{ST} 1(2)}=5.52 \Omega$. Short-line fault

3) $Z_{\mathrm{ST} 1(3)}=Z_{\mathrm{T} 1(\mathrm{n})}=2.05 \Omega ; R_{\mathrm{ST} 1(3)}=0.6 \Omega ; X_{\mathrm{ST} 1(3)}=1.96 \Omega$. Short-circuit for $\mathrm{T} 1$

4) $\underline{Z}_{\mathrm{ST} 1(4)}=0$.

Under the specified actual parameters of the PM elements the formula (3) is not applicable because

$$
Z_{\mathrm{T} 2(\mathrm{~L})} / Z_{\mathrm{G}}=0,83 / 4,68=0,177<K_{\mathrm{T} 3 \text { nom }} / K_{\mathrm{T} 2 \text { nom }}=1,
$$

which was taken into account in the course of the research and the results analysis.

To process the results of mathematical (digital) and physical modeling and their analysis, the values of linear voltages, phase currents and three-phase capacities have been used, which are presented in Tables 1,2 . In these tables, the following is indicated as DM for a digital model; PM for a physical model. The difference in the results of mathematical and physical modeling was calculated as a percentage of the expression:

$$
\delta \%=(\mathrm{DM}-\mathrm{PM}) / \mathrm{PM} \cdot 100 \%
$$

\begin{tabular}{|c|c|c|c|c|c|c|c|c|c|c|c|c|}
\hline \multirow[t]{2}{*}{ Value } & \multicolumn{3}{|c|}{ Mode 1} & \multicolumn{3}{|c|}{ Mode 2} & \multicolumn{3}{|c|}{ Mode 3} & \multicolumn{3}{|c|}{ Mode 4} \\
\hline & $\mathrm{DM}$ & $\mathrm{PM}$ & $\delta, \%$ & $\mathrm{DM}$ & PM & $\delta, \%$ & $\mathrm{DM}$ & $\mathrm{PM}$ & $\delta, \%$ & $\mathrm{DM}$ & $\mathrm{PM}$ & $\delta, \%$ \\
\hline $\mathrm{U}_{\mathrm{G}}, \mathrm{V}$ & 53.46 & 52.5 & 1.83 & 45.78 & 44.5 & 2.88 & 36.88 & 37.5 & -1.65 & 22.41 & 22.26 & 0.67 \\
\hline $\mathrm{I}_{\mathrm{G}}, \mathrm{A}$ & 2.31 & 2.23 & 3.59 & 2.76 & 2.71 & 1.85 & 3.91 & 3.81 & 2.62 & 5.81 & 5.58 & 4.12 \\
\hline $\mathrm{P}_{\mathrm{G}}, \mathrm{W}$ & 171.9 & 161.3 & 6.57 & 94.71 & 90.0 & 5.23 & $117 . .1$ & 120.0 & -2.42 & 133.7 & 145.5 & -8.11 \\
\hline $\mathrm{U}_{\mathrm{Aux}}, \mathrm{V}$ & 30.35 & 29.4 & 3.23 & 27.0 & 26.25 & 2.86 & 23.68 & 23.55 & 0.55 & 18.47 & 18.75 & 0.11 \\
\hline $\mathrm{I}_{\text {Aux }}, \mathrm{A}$ & 2.12 & 2.06 & 2.91 & 1.86 & 1.81 & 2.76 & 1.65 & 1.64 & 0.61 & 1.25 & 1.27 & -1.57 \\
\hline $\mathrm{P}_{\text {Aux }}, \mathrm{W}$ & 79.85 & 75.0 & 6.47 & 60.9 & 57.6 & 5.73 & 46.08 & 45.6 & 1.05 & 26.76 & 27.6 & -3.04 \\
\hline $\mathrm{U}_{\mathrm{ST} 1}, \mathrm{~V}$ & 33.2 & 31.5 & 5.4 & 26.08 & 25.2 & 3.49 & 16.34 & 16.16 & 1.11 & 0 & 0 & - \\
\hline $\mathrm{I}_{\mathrm{ST} 1}, \mathrm{~A}$ & 1.65 & 1.57 & 5.1 & 2.68 & 2.59 & 3.47 & 4.61 & 4.56 & 1.1 & 7.91 & 7.57 & 4.49 \\
\hline $\mathrm{P}_{\mathrm{ST} 1}, \mathrm{~W}$ & 85.95 & 80.4 & 6.9 & 21.45 & 21.0 & 2.14 & 38.34 & 37.5 & 2.24 & 0 & 0 & - \\
\hline $\mathrm{I}_{\mathrm{T} 2}, \mathrm{~A}$ & 1.21 & 1.17 & 3.42 & 0.85 & 0.78 & 8.97 & 1.27 & 1.35 & -5.93 & 3.5 & 3.75 & -6.67 \\
\hline $\mathrm{U}_{\mathrm{T} 3}, \mathrm{~V}$ & 20.26 & 19.85 & 2.07 & 19.69 & 19.33 & 1.86 & 20.54 & 20.75 & -1.01 & 22.41 & 22.26 & 0.67 \\
\hline
\end{tabular}

Table 1. Coordinates of the PU and AAT scheme modes.

The evaluation of the differences in the results of mathematical and physical modeling was carried out according to the values of their modules. The limits of the mode coordinates divergences for the PU with an AAT (A) and a traditional circuit $(\mathrm{T})$ are respectively: $\delta \mathrm{U}_{\mathrm{A}}=(0.11 \div 5.4) \%$ and $\delta \mathrm{U}_{\mathrm{T}}=(0.65 \div 7.93) \% ; \quad \delta \mathrm{I}_{\mathrm{A}}=(0.61 \div 8.97) \%$ and $\delta \mathrm{I}_{\mathrm{T}}=(0.17 \div 8.04) \% ; \delta \mathrm{P}_{\mathrm{A}}=(1.05 \div 8.11) \%$ and $\delta \mathrm{P}_{\mathrm{T}}=(1.29 \div 9.71) \%$. Consequently, the largest limits divergences values were applicable for active capacities.

The limits of the mode coordinates divergences for each of the characteristic modes under investigation are as follows: $\quad \delta \mathrm{M} 1_{\mathrm{A}}=(1.83 \div 6.9) \% \quad$ and $\quad \delta \mathrm{M} 1_{\mathrm{T}}=(4.36 \div 9.57) \% ; \quad \delta \mathrm{M} 2_{\mathrm{A}}=(1.85 \div 8.97) \% \quad$ and $\quad \delta \mathrm{M} 2_{\mathrm{T}}=(1.2 \div 4.0) \%$; $\delta \mathrm{M} 3_{\mathrm{A}}=(0.55 \div 5.93) \%$ and $\delta \mathrm{M} 3_{\mathrm{T}}=(0.17 \div 9.71) \% ; \delta \mathrm{M} 4_{\mathrm{A}}=(0.11 \div 6.67) \%$ and $\delta \mathrm{M} 4_{\mathrm{T}}=2.94 \%$. Consequently, the 
discrepancies have the highest values for modes 1 (M1) and 2 (M2), that is, during the normal mode of power output to the system and during the mode of the remote from a three-phase PU short circuit in the electrical network system, respectively. It is likely that this is due to the higher voltage level in these modes (especially in M1) as compared to the other ones and the influence of nonlinear elements in the physical model, as well as the absence of traversal branches in transformers' alternative circuits in mathematical model and the linearity of state equations.

Table 2. Modes coordinates of the traditional PU circuit (without an AAT).

\begin{tabular}{|c|c|c|c|c|c|c|c|c|c|c|c|c|}
\hline \multirow[t]{2}{*}{ Value } & \multicolumn{3}{|c|}{ Mode 1} & \multicolumn{3}{|c|}{ Mode 2} & \multicolumn{3}{|c|}{ Mode 3} & \multicolumn{3}{|c|}{ Mode 4} \\
\hline & $\mathrm{DM}$ & $\mathrm{PM}$ & $\delta, \%$ & $\mathrm{DM}$ & PM & $\delta, \%$ & $\mathrm{DM}$ & PM & $\delta, \%$ & $\mathrm{DM}$ & $\mathrm{PM}$ & $\delta, \%$ \\
\hline $\mathrm{U}_{\mathrm{G}}, \mathrm{V}$ & 47.92 & 45.92 & 4.36 & 33.97 & 33.55 & 1.25 & 20.03 & 19.7 & 1.68 & 0 & 0 & - \\
\hline $\mathrm{I}_{\mathrm{G}}, \mathrm{A}$ & 3.43 & 3.27 & 4.89 & 4.13 & 4.04 & 2.23 & 5.9 & 5.91 & -0.17 & 8.25 & 8.5 & -2.94 \\
\hline $\mathrm{P}_{\mathrm{G}}, \mathrm{W}$ & 249.0 & 231.3 & 7.65 & 68.37 & 67.5 & 1.29 & 78.99 & 72 & 9.71 & 0 & 0 & - \\
\hline $\mathrm{U}_{\mathrm{Aux}}, \mathrm{V}$ & 26.16 & 25.0 & 4.64 & 18.57 & 18.35 & 1.2 & 11.01 & 10.6 & 3.87 & 0 & 0 & - \\
\hline $\mathrm{I}_{\text {Aux }}, \mathrm{A}$ & 1.82 & 1.74 & 4.6 & 1.28 & 1.26 & 1.59 & 0.74 & 0.71 & 4.23 & 0 & 0 & - \\
\hline $\mathrm{P}_{\text {Aux }}, \mathrm{W}$ & 56.52 & 51.6 & 9.53 & 28.59 & 27.9 & 2.47 & 11.19 & 10.5 & 6.57 & 0 & 0 & - \\
\hline $\mathrm{U}_{\mathrm{sT1} 1}, \mathrm{~V}$ & 47.92 & 44.4 & 7.93 & 33.97 & 33.3 & 2.01 & 20.03 & 19.9 & 0.65 & 0 & 0 & - \\
\hline $\mathrm{I}_{\mathrm{ST} 1}, \mathrm{~A}$ & 2.41 & 2.24 & 8.04 & 3.46 & 3.4 & 1.76 & 5.52 & 5.48 & 0.73 & 8.25 & 8.5 & -2.94 \\
\hline $\mathrm{P}_{\mathrm{ST} 1}, \mathrm{~W}$ & 187.7 & 171.3 & 9.57 & 37.44 & 36.0 & 4.0 & 66.87 & 66 & 1.32 & 0 & 0 & - \\
\hline $\mathrm{I}_{\mathrm{T} 2}, \mathrm{~A}$ & 1.82 & 1.74 & 4.6 & 1.28 & 1.24 & 3.23 & 0.74 & 0.71 & 4.22 & 0 & 0 & - \\
\hline
\end{tabular}

In general, the divergences did not exceed $10 \%$ and were conditioned by the influence of the following main factors:

a) during mathematical modeling the experimentally set values of PM elements were used (i.e., not accurate because they are unknown, but with certain errors), the traversal branches and nonlinear characteristics of PM elements were neglected;

b) during physical modeling, there occurred errors of measurable complexes and devices and visual impairment errors.

Therefore, we can assume that developed mathematical and digital models can ensure the accuracy of computer simulation results, sufficient for adequate reflection and study and operational properties of the PU electrical part with an AAT.

For a comparative analysis of natural properties of the PU schemes with an AAT (A) and the traditional scheme of the PU (T) refer to Table 3, which shows the values of the voltages on the generator's leads and on the auxiliary busbars, calculated from the data of Table 1,2 in relation to nominal units of $U_{G \text { nom }}=50 \mathrm{~V}$ and $U_{\text {Aux nom }}=30 \mathrm{~V}$, correspondingly.

Table 3. Voltages in relative nominal units.

\begin{tabular}{|c|c|c|c|c|c|c|}
\hline \multirow{2}{*}{ Mode } & \multirow{2}{*}{$Z_{\mathrm{ST} 1}, \Omega$} & \multirow{2}{*}{ Model } & \multicolumn{2}{|c|}{ PU scheme with AAT } & \multicolumn{2}{c|}{ Traditional PU scheme } \\
\cline { 4 - 7 } & & & $\mathrm{U}_{\mathrm{G} \mathrm{A}^{*}}$ & $\mathrm{U}_{\text {Aux A }}$ & $\mathrm{U}_{\mathrm{G} \mathrm{T}} *$ & $\mathrm{U}_{\text {Aux T* }}$ \\
\hline \hline \multirow{2}{*}{1} & \multirow{2}{*}{11.59} & $\mathrm{DM}$ & 1.07 & 1.01 & 0.96 & 0.87 \\
\cline { 4 - 7 } & & $\mathrm{PM}$ & 1.05 & 0.98 & 0.92 & 0.83 \\
\hline \multirow{2}{*}{2} & \multirow{2}{*}{5.62} & $\mathrm{DM}$ & 0.92 & 0.9 & 0.68 & 0.62 \\
\cline { 4 - 7 } & & $\mathrm{PM}$ & 0.89 & 0.88 & 0.67 & 0.61 \\
\hline \multirow{2}{*}{3} & \multirow{2}{*}{2.05} & $\mathrm{DM}$ & 0.74 & 0.79 & 0.4 & 0.37 \\
\cline { 3 - 7 } & & $\mathrm{PM}$ & 0.75 & 0.79 & 0.39 & 0.35 \\
\hline \multirow{2}{*}{4} & \multirow{2}{*}{0} & $\mathrm{DM}$ & 0.45 & 0.62 & 0 & 0 \\
\cline { 4 - 7 } & & $\mathrm{PM}$ & 0.45 & 0.63 & 0 & 0 \\
\hline
\end{tabular}


Based on the data in Table 3 the dependencies of voltage on the generator's leads $\mathrm{U}_{\mathrm{G}} *$ and on the auxiliary busbars $\mathrm{U}_{\mathrm{Aux}}$ versus the value of the external module in relation to the equivalent resistance generator $Z_{\mathrm{ST} 1}$ between a node 3 and the system including block transformer, electrical network and the system load were built (see Fig. 3). This made it possible to investigate the voltage levels both in the normal mode 1 of the power output to the system and during the stable modes 2, 3, 4 of the three-phase short circuits in different points of the system.

The results analysis (Table 3 and Fig. 3) has shown almost complete matches received on digital and physical models of generator output voltage dependence on generator leads and auxiliary busbars, which characterize the natural properties of both the electrical part scheme of the PU with an AAT and the traditional scheme of the PU without an AAT. It is known that in the traditional scheme, depending on the short circuit location, the voltage on the generator's outputs $\mathrm{U}_{\mathrm{GT}} *$ and on the auxiliary busbars $\mathrm{U}_{\mathrm{AuxT}}$ are reduced from their values during normal power delivery to the system (mode 1) to zero during the short circuits on the outputs of a primary winding LV T1 (mode 4). In this case, already during the non-remote short circuits (mode 2) and, even more so during the short circuit the secondary winding in HVT1 (mode 3), the voltage value on the auxiliary busbars becomes less than possible for the operation of electrical receivers $\left(\mathrm{U}_{\mathrm{AuxT}} *<0.7\right)[12]$.
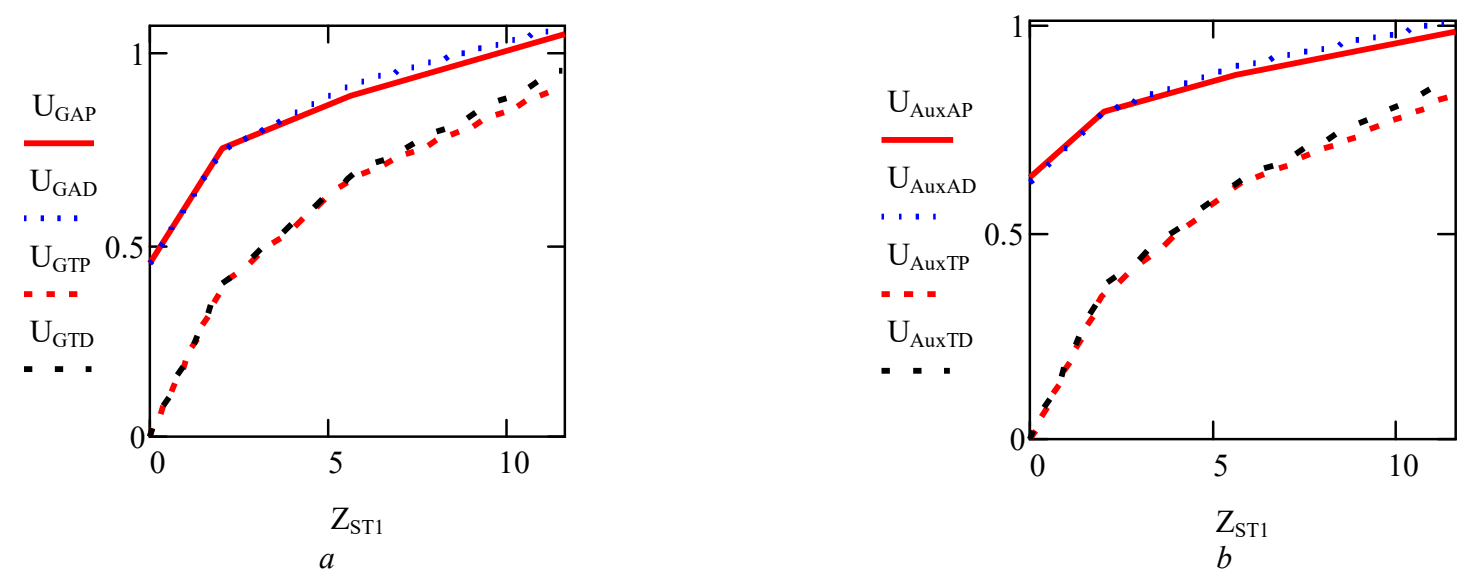

Fig. 3 Voltage dependence for digital (D) and physical (P) scheme models of the PU with an AAT(A)and a traditional scheme of the PU without an AAT (T) from resistance $\mathrm{Z}_{\mathrm{ST} 1}: a-\mathrm{U}_{\mathrm{G}^{*}} ; b-\mathrm{U}_{\mathrm{Aux}^{*}}$.

In the PU scheme with an AAT, unlike the traditional one, the voltage values on the outputs of the generator $\mathrm{U}_{\mathrm{GA}^{*}}$ and on the auxiliary busbars $\mathrm{U}_{\mathrm{Aux} \mathrm{A}^{*}}$ during the analogous modes analyzed above are always more than zero. IT should be noted that the correlations of the actual parameters of PM elements (6) are far from the desired condition (1) $\div(3)$. However, even with this, in all modes, except for the short circuit on the outputs of the primary low voltage LVT1 winding (mode 4), the level of residual voltage on the auxiliary busbars $\mathrm{U}_{\mathrm{Aux}^{*}} \geq 0.7$ is secured, sufficient for the work of their electrical receivers[12].

\section{Conclusion}

1) Experiments on a static physical model of a fragment of an electrical part of a power unit with an additional working auxiliary transformer have proved that the natural properties of the investigated circuit provide its operation in a mode close to the current source mode, the value of which is determined by the current load of the PU.

2) It has been shown that despite the significant deviations of the ratio parameters of PM PU main elements with an AAT from the optimal values of its natural properties are preserved and, unlike the traditional PU without an AAT, provide the level of residual voltage on the auxiliary PU busbars, sufficient for the operation of their electrical receivers in three-phase short-circuit modes.

3) Comparative analysis and the evaluation of the differences of mathematical and physical modeling results of the PU with and without an AAT have confirmed the research effectiveness using appropriate mathematical and digital models of such schemes and software systems that provide the required accuracy of the results. 


\title{
References
}

[1] PatentNo. 39640A.Electricity auxiliary supply system of the power plant power unit / Lysiak H. M., Malinovskyy A. A., Nykonets L. O., Bulletin No 5. - 2001.(in Ukrainian)

[2] Lysiak H. M., Malinovsky A. A., Pastukh O. R. The method of selecting the main parameters of the scheme of increased reliability of block power plants from the conditions for maintaining the desired voltage level on the buses of own needs during external three-phase short circuits // Technical electrodynamics. -2000 No. 4- P. 51-55. (in Ukrainian)

[3] Lysiak H. M., Pastukh O.Operating States and Characteristics of Power Plant Unit Comprising Additional Operating Auxiliaries Transformer. //Proceedings of Vinnytsia Polytechnic Institute. - 2016. No. 2 (125). - p. 116-121. (in Ukrainian)

[4] Lysiak H.M., Pastukh O.R., Ravlyk O.M. Transient processes during external short circuits of a power unit with an additional working transformer of own needs // Proceedings of Lviv Polytechnic National University - Lviv. 2010.- No. 671.- p. 51-57. (in Ukrainian)

[5] Lysiak H. M., Pastukh O.R., Ravlyk O.M. External short circuit modes of the unit with an additional working transformer of own needs // Proceedings of Lviv Polytechnic National University- 2009.- No. 654.-p. 125-132. (in Ukrainian)

[6] Lysiak H. M., Pastukh O. R. Estimation of voltage levels during the established modes of power units with an additional working transformer for own needs // Proceedings of Lviv Polytechnic National University "Electric power and electromechanical systems". 2008. No. 615. p. 58-64. (in Ukrainian)

[7] Lysiak H. M.,Pastukh O.R. Estimation of the voltage level range of change on auxiliary busbars on power units increased reliability circuit schemes in external three-phase short circuits// Proceedings of Lviv Polytechnic National University "Electric power and electromechanical systems". - Lviv. No. 435. - 2001. - p. 77-84. (in Ukrainian)

[8] Lysiak H. M., Pastukh O.R., Skrypnyk O.I., Konoval V. S. Computer simulation of established modes of power generators with an additional working transformer of own needs// Proceedings of Lviv Polytechnic National University.- 2003.- No. 487.- p. 81-88. (in Ukrainian)

[9] O. Skrypnyk. DAKAR - computing complex of the analysis of modes and processes of electric power systems // Technical electrodynamics. 1998. - Special issue - p. 56-61. (in Ukrainian)

[10] Ravlyk A. Digital complex for modeling of transient processes in electric circuits / A. Ravlyk, T. Grechyn. // Mathematical Methods in Electric Power Engineering: III Symposium.- Zakopane. Poland.- 1993.- p. 17-20.

[11] Burshtynsky M. V., Hay M. V. Devices of protection and control in low-voltage electrical installations: course book / M. V. Burshtynsky, M. V. Hay - 3rd edition supplemented and redone - Lviv Polytechnic National University. 2011 - p. 308. (in Ukrainian)

[12] Guk Y. B., Kobzhuv V. M., Chernovetz A. K. Installation, design and operation of power supply schemes for own needs of nuclear power plants. - Moscow: Energoatomizdat.1991- p. 296. (in Russian)

\section{Фізичне моделювання енергоблоку електростанції 3 додатковим робочим трансформатором власних потреб}

\author{
Георгій Лисяк, Олена Пастух, Богдан Харчишин
}

Національний університет «Львівська політехніка», вул. С. Бандери, 12, м. Львів, 79013, Україна

\section{Анотація}

Показано варіант схеми першого ступеня трансформації системи живлення власних потреб енергоблоку (ЕБ). Електропостачання приймачів власних потреб здійснюється від генератора через робочий та додатковий робочий трансформатори власних потреб (ДРТВП). Спосіб увімкнення ДРТВП забезпечує його роботу в режимі джерела заданого навантаженням ЕБ струму. Проведено експерименти на статичній фізичній моделі фрагмента схеми системи живлення власних потреб з ДРТВП. Підтверджено, що пї природні властивості, на відміну від традиційних схем, забезпечують під час нормальних режимів, режимів зовнішніх коротких замикань рівень напруги на шинах власних потреб, достатній для надійної роботи їх електроприймачів. Доведено можливість ефективного проведення досліджень 3 застосуванням відповідних математичних і цифрових моделей, підтверджено високу адекватність одержуваних результатів.

Ключові слова: електростанція; трансформатор власних потреб; енергоблок; схема. 